\title{
Structural Vector Autoregressive Analysis of Monetary Policy in Thailand
}

\author{
Popkarn Arwatchanakarna
}

\begin{abstract}
This paper highlights the importance of monetary policy transmission mechanism in Thailand since the 1997 financial crisis and then undertakes an empirical investigation of Thailand monetary policy. This study makes effort to address both two aspects of monetary transmission mechanism, namely channels of monetary policy and the effect of monetary policy shocks on key macroeconomic variables. To address these issues, the paper specifies structural vector autoregressive (SVAR) models and estimates them using quarterly data from 1997q3 to 2014q4. The identification schemes used in this paper follow Kim and Roubini and Raghavan, Silvapulle, and Athanasopoulos with some modifications. The overall result is that the identifying restrictions used in the SVAR seem to appropriately identify a monetary policy shock even though the exchange rate puzzle is found. The results show that interest rate and monetary aggregate have played the dominant channels of monetary transmission mechanism in Thailand, while an exchange rate channel is decreasingly significant. In addition, Thailand economy is somewhat exposed to the foreign sector especially for the world price of oil and the U.S. monetary policy. The results also reveal the linkage and influence of U.S. monetary policy on Thailand monetary policy. The empirical findings are then used to provide Bank of Thailand (BOT) with insight into identifying the important monetary policy transmission channels. It would help the BOT to implement an effective monetary policy for achieving price stability through the appropriate monetary channels.
\end{abstract}

Keywords

Monetary policy, monetary transmission mechanism, SVAR model, Thailand

A critical understanding of money policy in an open-economy context is essential for price stability and sustained economic growth ${ }^{1}$. That is, the effectiveness of monetary policy in improving economic performance mainly relies on how well policy makers understand the monetary transmission mechanism $^{2}$. Thus, policy-oriented research for identifying some major channels of how monetary policy is transmitted in the economy is increasingly important in recent decades. However, particularly in Thailand, the knowledge and understanding of the monetary policy transmission mechanism is somewhat limited.

After the 1997 financial crisis, Thailand has dramatically changed the exchange rate regime and implemented economic reforms suggested by the International Monetary Fund (IMF). Given an institutional reform of monetary policy, a managed-float exchange rate system and a rule-based

aThe University of Newcastle, Australia

Correspondent Author:

Popkarn Arwatchanakarn, Newcastle Business School, University Drive, Callaghan, NSW 2308, Australia 
monetary policy, namely monetary targeting and inflation targeting, have been introduced. In doing this, monetary transmission mechanism has been also changed. The understanding of monetary transmission mechanism in Thailand needs to be reinvestigated. However, there has been the limited number of studies that have been conducted on the monetary policy transmission mechanism in developing countries like Thailand. The contribution of this study is to provide the quantitative importance of a rule-based monetary policy on a bunch of macroeconomic variables. The study makes effort to address the issues of monetary policy transmission mechanism in Thailand. To achieve this purpose, a structural vector autoregressive model, henceforth SVAR, is built for Thailand monetary policy analysis. The identification of the SVAR model is developed based on theoretical basis and previous studies. An analysis of the impulse responses and forecast error-correction decompositions is then made to draw the empirical findings.

The organization of this paper is as follows. Section 2 reviews the theoretical and empirical literature on monetary policy transmission mechanism. Section 3 develops an SVAR model that is used to analyze the monetary transmission mechanism in Thailand. The empirical results are reported in section 4. Final section offers some concluding remarks and policy implications.

\section{LITERATURE REVIEW ON MONETARY POLICY TRANSMISSION MECHANISM AND THAI MONETARY POLICY}

This section briefly reviews literature on monetary policy transmission mechanism and discusses on Thai monetary policy including the application of SVAR model to monetary analysis.

\section{Monetary Policy Transmission Mechanism}

As stated by Taylor (1995), monetary policy transmission mechanism refers to "the process through which monetary policy decision is transmitted into real GDP and inflation”. There are many aspects of monetary transmission mechanism depending on which channel they emphasize namely money, interest rate, credit, exchange rate, and asset price channel. However, some economists have focused on only a particular channel of monetary transmission. For an example, Mishkin (1995) emphasized that the interest rate channel has been a standard feature of monetary policy transmission. Meanwhile, this channel is the heart of transmitting monetary policy in Keynesian view. Since the late 1980s, credit has emerged as an important channel for the monetary transmission mechanism (Bernanke 1986; Bernanke and Blinder 1988). Consistent with studies by Bernanke and Blinder (1992) and Bernanke and Gertler (1995), they support the existence and significance of credit channel. In addition, Taylor (1995) emphasized that the increasing role of the exchange rate channelas has to be taken into consideration in open economies.

\section{Thailand Monetary Policy}

Since July 2, 1997, Thailand monetary policy strategy has been significantly changed in terms of the exchange rate regime and the independent conduct of monetary policy. It has adopted a managed-float exchange rate regime with some restrictions on capital flows. This has given the Bank of Thailand (BOT, central bank of Thailand) some autonomy in the design and conduct of monetary policy. The significant changes in monetary policy are not only necessary to establish a new monetary strategy that has brought to price stability but also expect to insulate the economy from external shocks.

Given an institutional reform of monetary policy for price stability, a rule-based monetary policy has been introduced since the 1997 financial crisis. In the midst of the financial crisis, Thailand's monetary policy took the form of monetary targeting during July 1997-May 2000. Then, the BOT has switched to 
"flexible inflation targeting" that aims to keep both inflation and output stable since May 2000. In hindsight, this was a correct decision because it supports Thailand to maintain price stability (Hossain 2009). An appropriate inflation targeting is supportive of sustainable economic growth at least three ways. First, low and stable inflation would enable the economy to grow on a sustainable path. Second, it would maintain the country's export competitiveness if domestic inflation is comparable to trading partners and competitors' inflation rates. Third, the low inflationary environment would build up the confidence of consumer and business enterprises.

Presently, the inflation targeting strategy encourages the BOT to pay considerable attention not only to contain inflation but also to stabilize economic growth. The BOT sets a short-term interest rate, that is the 1-day repurchase rate, as the key monetary instruments for demand management. In brief of monetary transmission, changes in short-term policy interest rate affect the medium- and long-term interest rates, asset prices, and exchange rates. Consequently, changes in these prices affect aggregate demand, inflationary pressure, and hence economic activity (Hossain 2009). During the inflation targeting, the BOT has made some adjustments on type and range of inflation target to strengthen the effectiveness of monetary policy in anchoring long-run inflation expectation ${ }^{3}$.

In overview, inflation targeting has been satisfactorily instrumental to institutional reforms and improved macroeconomic management in Thailand. It has elevated the BOT as the key institution that makes monetary policy credible and effective in maintaining price stability (Nakornthab 2009). In a past decade, the inflation targeting has been successful in keeping inflation low on average and lowered vulnerability to external shocks (Grenville and Ito 2010; Lane et al. 2000). However, the issue of monetary transmission mechanism in Thailand has been topical among policymakers and academicians. There is a room for investigation especially when monetary policy landscape and global environment has changed. The more understanding would enhance the effectiveness of monetary policy in Thailand.

As reviewing the empirical studies, a number of monetary literatures in Thailand have paid considerable attention to the issue of monetary transmission mechanism since the 1997 financial crisis. A vector autoregression (VAR) is extensively used as an econometric tool for monetary policy analysis, see for example Fung (2002), Disyatat and Vongsinsirikul (2003), and Charoenseang and Manakit (2007a; 2007b). However, a growing body of literature analyzes monetary transmission mechanisms by employing a structural vector autoregression (SVAR) model. An SVAR model is also more interesting, advantageous, and realistic compared to a standard VAR model because we can use some economic theories, previous studies, and stylized facts to impose the restrictions for our analysis. Thus, macroeconomists prefer to use SVAR rather than VAR in order to address the issues of monetary transmission mechanism. Although the SVAR models have been extensively applied for industrialized economies, they have not been much used for Thailand. As empirical literature of Thailand ${ }^{4}$, interest rate channel is found to be a key monetary transmission mechanism in both the pre- and post-1997 crisis (Atchariyachanvanich 2004; Hesse 2007; Kubo 2008). However, the exchange rate has still been important in monetary policy action (Sek 2009). In addition, Atchariyachanvanich (2004) found evidence that asset price channel has increasing role in transmitting monetary policy after the 1997 crisis. Therefore, the critical issue of monetary transmission mechanism still remains and needs to be reinvestigated. To fill the monetary literature in Thailand, this study aims to build an SVAR model for monetary policy analysis under inflation targeting framework. 


\section{METHODOLOGY}

A growing body of literature analyzes the monetary policy transmission mechanism by employing the SVAR model. An SVAR model represents a multivariate system of a set of endogenous variables, which maintain feedback relations in a dynamic sense. The variables of the SVAR model are then assumed to be contemporaneously and dynamically interdependent.

\section{SVAR Framework}

As pioneered by Sims (1986) and Bernanke (1986), they proposed SVAR modelling using economic analysis. It is useful to examine the relationship between forecast errors and structural innovations in an n-variable VAR. In a modelling sense, an SVAR has the following general form:

$$
A_{0} Y_{t}=A_{1}(L) Y_{t}+B \varepsilon_{t}
$$

Where $\mathrm{Y}$ is a $(n \times 1)$ vector of macroeconomic variables; $A_{0}$ and $B$ are $(n \times n)$ vectors of parameters; $\quad A_{1}(L)=\sum_{i=1}^{n} A_{1 i} L^{i} \quad$ is a matrix polynomial in the lag operator; and $\varepsilon_{t}$ is a $(n \times 1)$ vector of structural shocks.

Pre-multiplying equation (1) with $A_{0}^{-1}$, a reduced form VAR is specified:

$$
Y_{t}=C(L) Y_{t}+e_{t}
$$

Where $C(L)=A_{0}^{-1} A_{1}(L) ; e_{t}$ represents a vector of reduced-form residual, that is, $A_{0}^{-1} B \varepsilon_{t}$.

In compact form, an SVAR system relates to the following relations:

$$
A_{0} e_{t}=B \varepsilon_{t}
$$

The equation (3) is known as the $\mathrm{AB}$ model (Amisano and Giannini 1997). Where $A_{0}$ is $(n \times n)$ matrix of contemporaneous relations between endogenous variables, $\mathrm{B}$ is $(n \times n)$ matrix that linearly relates the SVAR residuals to the structural innovations, $e_{t}$ is vector of reduced-form residual, and $\varepsilon_{t}$ is vector of structural shocks. The residual $e_{t}$ in the reduced form is presumed to be white noise. Therefore, we can estimate the $\mathrm{AB}$ model by OLS
(Ordinary Least Squares).

\section{SVAR Specification}

Importantly, the employment of SVAR for this study is motivated by the idea that SVAR models are useful tool to analyze the dynamics of a model. In addition, the SVAR uses economic theory to impose the contemporaneous relationships among the variables. This study follows Kim and Roubini (2000) and Raghavan, Silvapulle, and Athanasopoulos (2012). The SVAR model is built under an assumption of a small open economy. The basic reason behind the model is that Thailand is a small open economy and is largely influenced by global economy. Thus, it means that domestic shocks do not affect a change in external environment. In contrast, shocks to the foreign variables are expected to have significant impacts on the Thai economy. This study specifies a seven-variable SVAR model as follows:

$$
Y_{t}=[O P I, U S F F R, R G D P, T H C P I, N M, T H C B P R, N E E R]^{\prime}
$$

In the SVAR system, the author includes such variables that are important for the foreign sector, the domestic goods market and the domestic money market. Of the seven variables, the first two variables represent international conditions namely oil price index (OPI) and US Federal Fund Rate (USFFR). These are included in the SVAR to account for non-policy induced inflationary expectations and the world financial condition respectively (Cushman and Zha 1997; Dungey and Pagan 2000; 2009; Kim and Roubini 2000). The remaining five variables are the standard set of variables in monetary literature representing domestic economy. They are output (RGDP), Thailand consumer price index (THCPI), monetary aggregate (narrow money, NM), Thailand central bank policy rate (THCBPR), and the nominal effective exchange rate (NEER). In order to examine the exchange rate channel, the author has included the nominal effective exchange rate model in the SVAR model. 


\section{Identification Issues}

In order to recover the structural parameters, the reduced form equation (2) is to be estimated. However, these estimates can be given meaningful economic interpretation if the structural system's parameters can be identified by imposing theory-consistent restrictions for equation (3).

In this study, the author imposes the restrictions on contemporaneous relationship among the variables based on the works of Kim and Roubini (2000), Sek (2009), and Raghavan et al. (2012) but modifies it in some aspects. The foreign block includes the world price of oil and U.S. monetary policy and it is assumed that domestic variables do not affect foreign variables contemporaneously. These two variables are identified recursively. The equation of oil price is assumed to be contemporaneously exogenous to all variables in the model. The equation of U.S. monetary policy is assumed to be contemporaneously affected by the oil price. The reason behind this restriction is to capture the reaction of the U.S. Federal Reserve Bank to oil-price related inflationary shock. The third and fourth equations represent the goods market behaviour.
The output equation is influenced contemporaneously by the oil price, but responds to price and financial signals (interest rate and exchange rate) by lags. The price equation is assumed to be contemporaneously affected by output and inflationary pressure of the oil price. The fifth and sixth rows are associated with money market behaviour. The money equation (M), represented as real money balance, follows the traditional money demand that is contemporaneously influenced by the interest rate $(\mathrm{R})$, income $(\mathrm{Y})$, and price (CPI). In this model, the monetary policy reaction function is modified to follow the Taylor rule that the policy interest rate reacts to price (CPI), output (Y), and exchange rate (E). Therefore, the monetary policy is contemporaneously affected by all variables in the model except money (M). The last row represents the exchange rate which is assumed to be contemporaneously affected by all variables in the SVAR system.

These restrictions are imposed on the contemporaneous relations between the structural shocks and the reduced form VAR residual. This identification scheme is represented in matrix form as follows:

$$
\left[\begin{array}{ccccccc}
1 & 0 & 0 & 0 & 0 & 0 & 0 \\
a_{21} & 1 & 0 & 0 & 0 & 0 & 0 \\
a_{31} & 0 & 1 & 0 & 0 & 0 & 0 \\
a_{41} & 0 & a_{43} & 1 & 0 & 0 & 0 \\
0 & 0 & a_{53} & a_{54} & 1 & a_{56} & 0 \\
a_{61} & a_{62} & a_{63} & a_{64} & 0 & 1 & 0 \\
a_{71} & a_{72} & a_{73} & a_{74} & a_{75} & a_{76} & 1
\end{array}\right]\left[\begin{array}{c}
e_{t}^{O P I} \\
e_{t}^{F F R} \\
e_{t}^{Y} \\
e_{t}^{C P I} \\
e_{t}^{M} \\
e_{t}^{R} \\
e_{t}^{E R}
\end{array}\right]=\left[\begin{array}{ccccccc}
b_{11} & 0 & 0 & 0 & 0 & 0 & 0 \\
0 & b_{22} & 0 & 0 & 0 & 0 & 0 \\
0 & 0 & b_{33} & 0 & 0 & 0 & 0 \\
0 & 0 & 0 & b_{44} & 0 & 0 & 0 \\
0 & 0 & 0 & 0 & b_{55} & 0 & 0 \\
0 & 0 & 0 & 0 & 0 & b_{66} & 0 \\
0 & 0 & 0 & 0 & 0 & 0 & b_{77}
\end{array}\right]\left[\begin{array}{c}
\varepsilon_{t}^{O P I} \\
\varepsilon_{t}^{F F R} \\
\varepsilon_{t}^{Y} \\
\varepsilon_{t}^{C P I} \\
\varepsilon_{t}^{M} \\
\varepsilon_{t}^{R} \\
\varepsilon_{t}^{E R}
\end{array}\right]
$$

The coefficients in the matrix $A_{0}$ give the contemporaneous relationships between variables. The coefficients in the main diagonal of the $B$ matrix give estimates of standard deviations of the structural shocks. The structural disturbances $\left(\varepsilon_{t}\right)$ stand for the shocks of oil price index $\left(\varepsilon_{t}^{O P I}\right)$, U.S. monetary policy $\left(\varepsilon_{t}^{F F R}\right)$, output $\left(\varepsilon_{t}^{Y}\right)$, consumer price index $\left(\varepsilon_{t}^{C P I}\right)$, monetary aggregate $\left(\varepsilon_{t}^{M}\right)$, interest rate $\left(\varepsilon_{t}^{R}\right)$, and exchange rate $\left(\varepsilon_{t}^{E R}\right)$ respectively. The residuals of reduced form $\left(e_{t}\right)$ on the left hand side can be interpreted as unexpected movement of variables in the system equation. For a seven-variable SVAR model, the contemporaneous matrix $\left(A_{0}\right)$ requires $\left(7^{2}-7\right) / 2=21$ restrictions to be just-identified model $^{5}$. Since the number of restriction on matrix $A_{0}$ is 25 , which is greater than 21 , the model is 
over-identified. However, The over-identification of the model needs to be statistically examined against the just-identified model (Afandi 2005).

\section{The Data Sources and Time-Series Properties of Variables}

Data for these variables are obtained from various issues of IMF's International Financial Statistics, World Bank's World Development Indicator, and Bank of Thailand. For model estimation, quarterly data and four lags are employed ${ }^{6}$. The sample period spans from 2000q2 to 2014q4 for a total of 59 observations. Most data have been transformed into logarithmic forms except for interest rates which are in percentages. To determine the time-series properties of each of the variables, two widely-used unit root tests: the augmented Dickey-Fuller (ADF) test and the Kwiatkowski, Phillips, Schmidt, and Shin (KPSS) test, are performed. The overall results ${ }^{7}$, not reported, suggest that the most variables under consideration have a unit root in a level form but are stationary in the first-order log-difference form.

\section{EMPIRICAL RESULTS}

This section reports and discusses the impulse response functions and the variance decomposition ${ }^{8}$.

\section{Impulse Response Function}

This section reports the accumulated impulse responses for the variables in the SVAR model as shown in Figures 1-3. The focus is on the impulse responses of Thailand variables to an interest rate shock and the relative responses of output, inflation to the world oil price, U.S. monetary policy, interest rate, money, and exchange rate shocks. Some interesting findings are discussed as follows.

Figure 1 reveals the impulse responses of all domestic variables to a standard deviation of monetary policy shock. While the estimated impulse responses do not produce a price, liquidity, and output puzzle, there is evidence of an exchange rate puzzle ${ }^{9}$. It implies that the restrictions used in the SVAR seem to appropriately identify a monetary policy shock. Following a shock of monetary policy interest rate, domestic output declines significantly within approximately two years. The largest fall in domestic output happens after five quarters. However, there are no significant responses of price level, monetary aggregate, and exchange rate as the zero line lies between the two-standard-error confidence bands.

Figure 2 shows the responses of output to various shocks (other than an interest rate shock). As the U.S. monetary policy shock, output declines quickly and significantly in first few quarters. Furthermore, domestic output has an adverse effect following an inflation and exchange after five quarters shock, but it occurs in very short period. The effect of a monetary aggregate shock seems to be positive on domestic output.

Figure 3 shows the response of inflation to other shocks. Inflation responds positively to both the world price of oil and domestic monetary aggregate, but it responds negatively to the U.S. monetary policy shock in the short run. The positive responses of prices to a shock of monetary aggregate are persistent. This implies that prices increase in response to a positive monetary shock and that monetary expansion is an important source of inflation in the long run. This result leads to a policy implication that monetary authority could use monetary aggregate as a supplementary instrument to control inflation and to stimulate output at least in the short run.

\section{Forecast Error Variance Decomposition}

Table 1 summarizes the variance decomposition of variables in the SVAR model, up to a period of five years. The fluctuations of some domestic variables are explained as follows. First, it can be seen that for domestic output, it is explained by its own innovation in the short run, but monetary aggregate makes a growing contribution to its forecast error variance over 

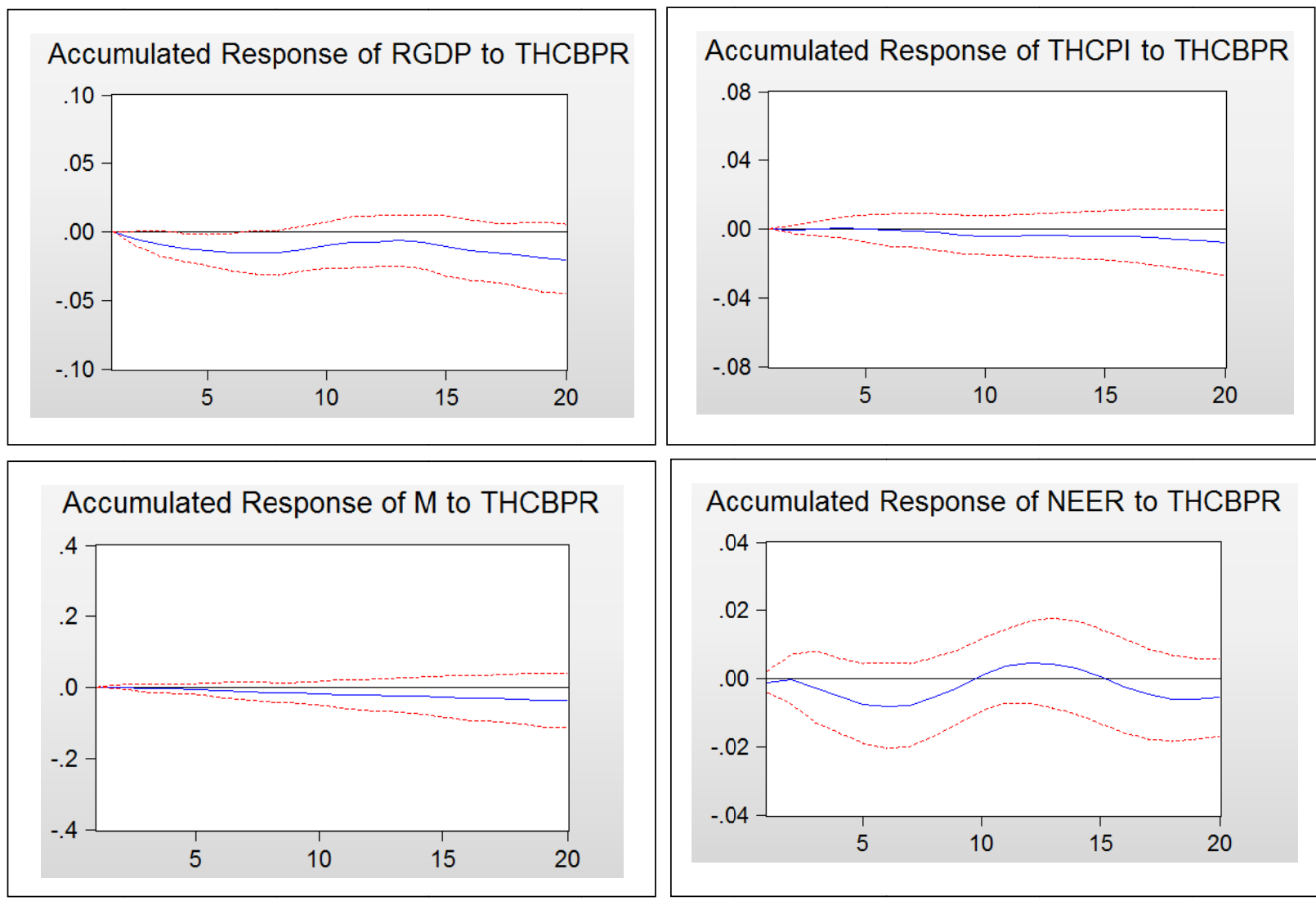

Accumulated Response of NEER to THCBPR

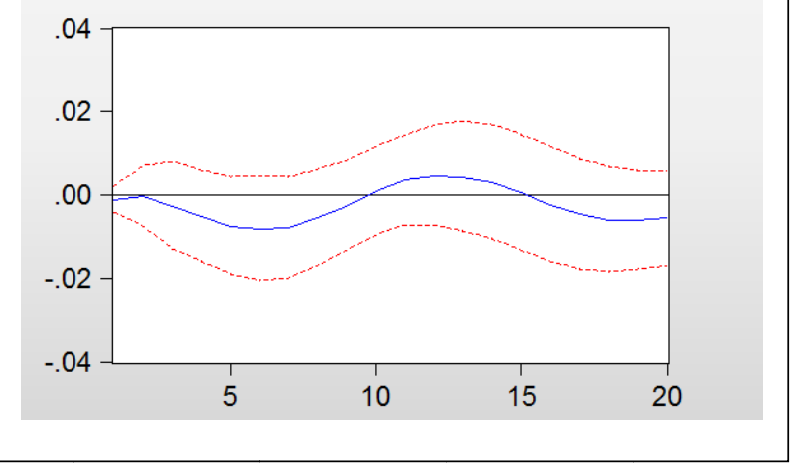

Figure 1. Impulse Responses of Thailand Variables to an Interest Rate Shock.

time. The contribution of monetary shocks that are monetary policy rate, money, and price, explains $40 \%-55 \%$ of output fluctuation within five years. The foreign blocks (USFFR and OPI) make a significant proportion, $19 \%-24 \%$, of output fluctuation in both the short and long run. It is important to note that real output is highly sensitive to domestic monetary shocks. Similar to the finding of Kim and Roubini (2000), monetary policy shocks (THCBPR) make a small proportion, but money shocks become a major source of output fluctuation.

In the case of price level, most of its fluctuation is explained by the shock of the world oil price in the short run, but it makes a decreasing proportion to the price fluctuation over time. However, monetary policy and money shocks explain substantial part of price fluctuation, about $23 \%-38 \%$, in both the short and long run. Considering that the world oil price, foreign monetary policy, and exchange rate are foreign sector, we can infer that more than half of price fluctuation, about $52 \%-65 \%$, is due to foreign sector.

In the case of monetary aggregate, most of its forecast error variance is explained by its own shock in the short and long run. While domestic sector that includes output, price, and monetary policy contributes a small proportion of $10 \%-14 \%$, foreign sector makes a contribution, about 23\%-29\% of forecast error variance of monetary aggregate.

In the case of monetary policy, if we consider that the monetary policy rate, money, and price are domestic monetary shock, more than half of forecast error variance of monetary policy in the short run is due to the monetary shock. As the horizon increases, while domestic monetary shock has a decreasing role, the impact of foreign monetary policy and exchange 
rate becomes more important. The U.S. monetary policy explains more than $20 \%$ of Thai monetary policy fluctuation in longer horizon. This implies that Thai monetary policy is linked and relatively sensitive to U.S. monetary policy.
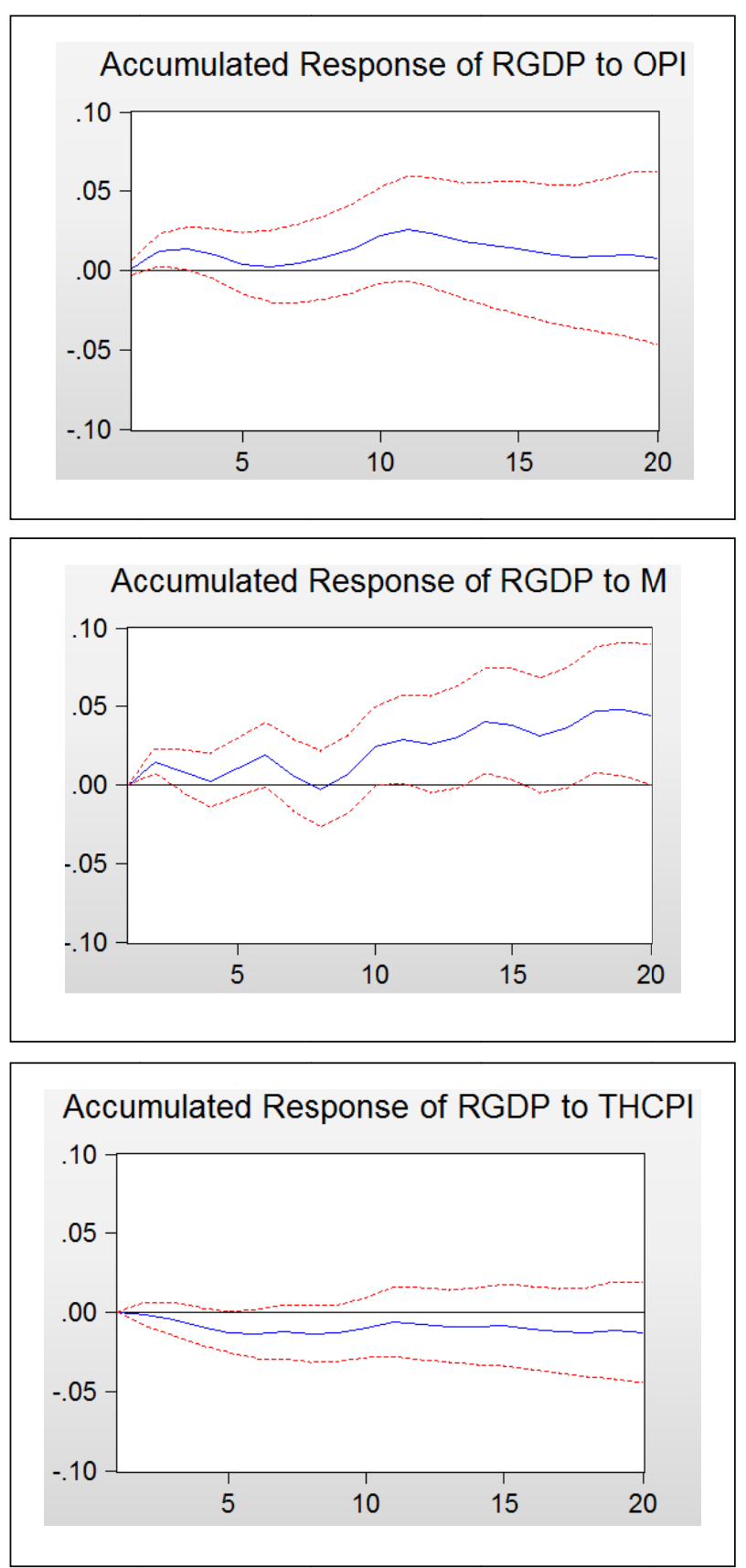

Figure 2. Impulse Response of Output to Various Shocks.

Another significant effect that is worth highlighting is the contribution of real output and monetary aggregate in the exchange rate. They jointly contribute about $40 \%-42 \%$ to the forecast error variance of exchange rate.

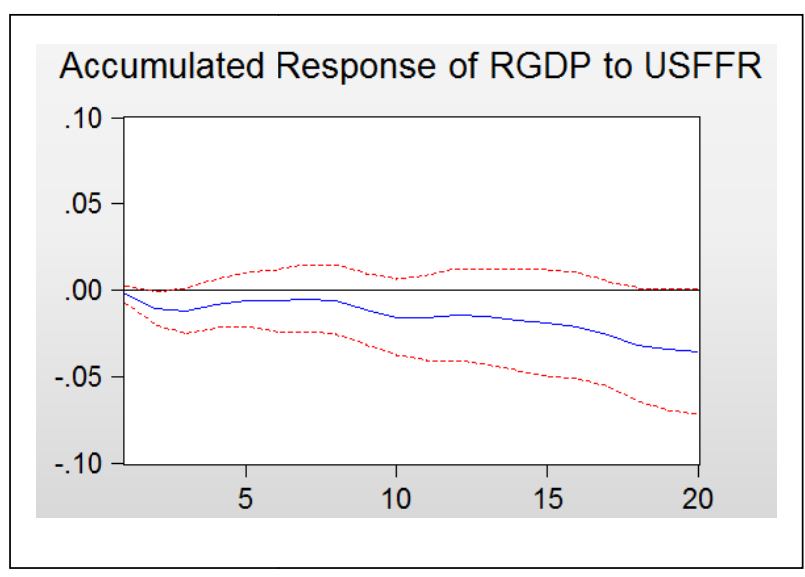

Accumulated Response of RGDP to THCBPR

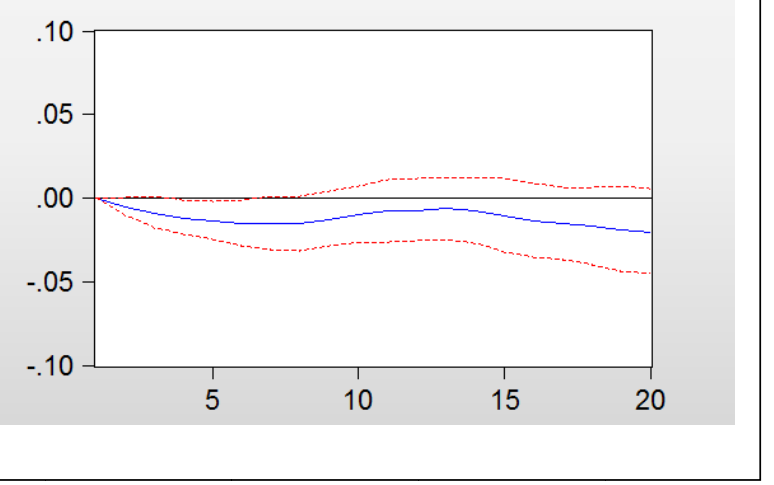

Accumulated Response of RGDP to NEER

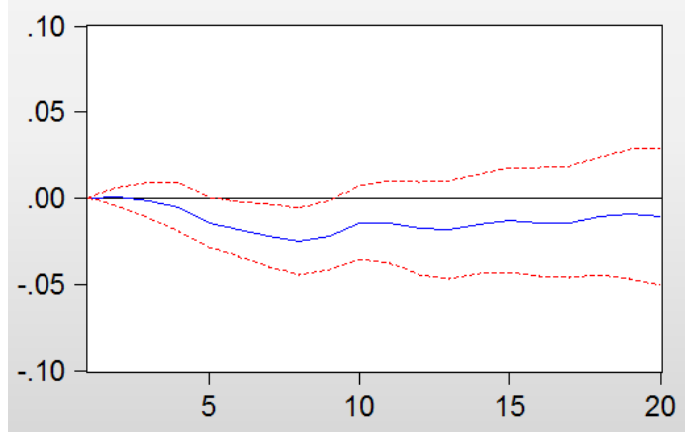



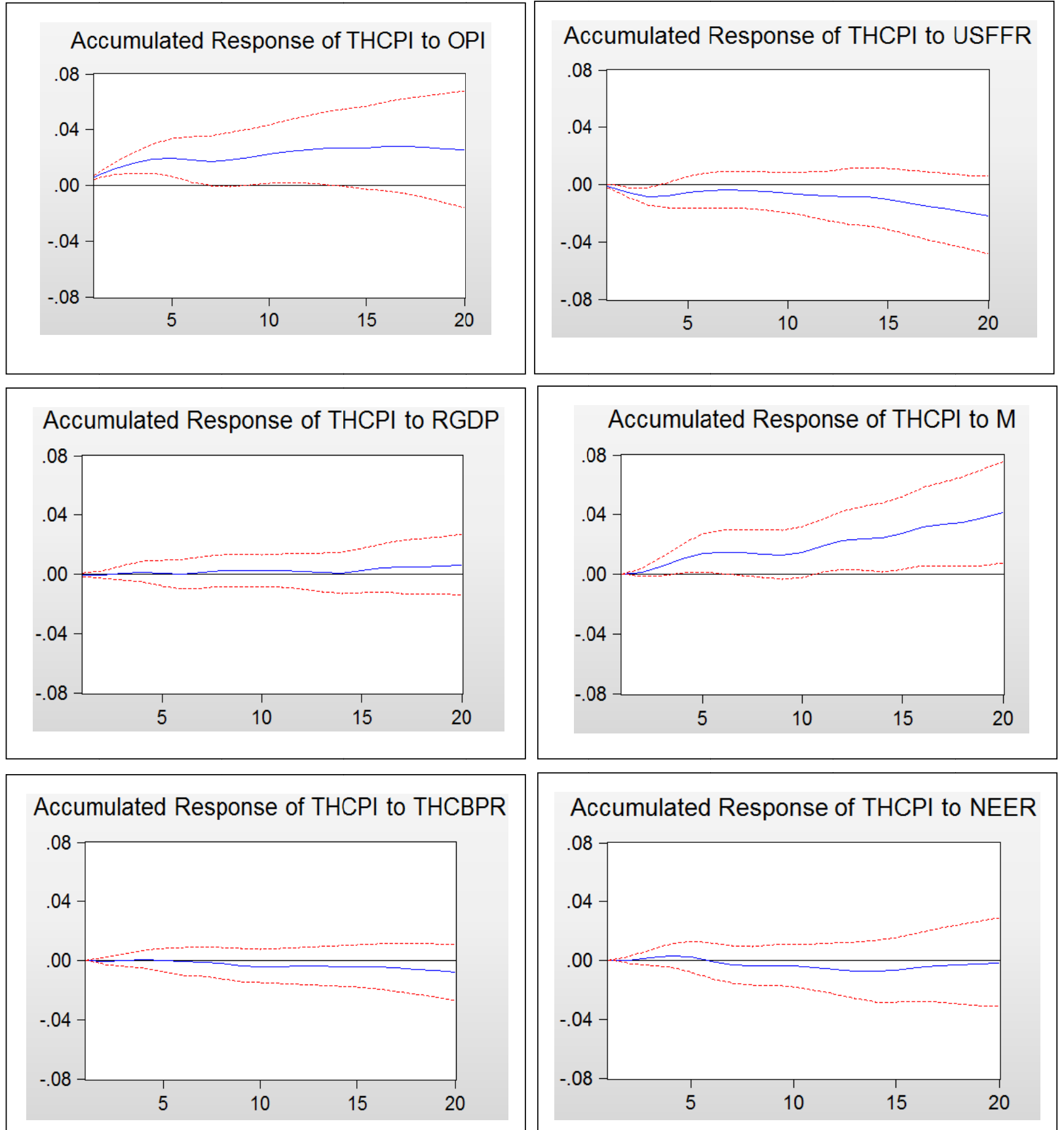

Figure 3. Impulse Response of Price Level to Various Shocks. 
Table 1. Forecast Error-Variance Decompositions for Seven Variables in an SVAR With Ordering: OPI, USFFR, RGDP, THCPI, M, THCBPR, and NEER

\begin{tabular}{|c|c|c|c|c|c|c|c|c|}
\hline $\begin{array}{l}\text { Time horizon } \\
\text { (quarter) }\end{array}$ & Standard error & OPI & USFFR & RGDP & THCPI & M & THCBPR & NEER \\
\hline \multicolumn{9}{|l|}{ OPI } \\
\hline 4 & .192 & 55.328 & 10.307 & 2.949 & 1.688 & 26.11 & 1.148 & 2.458 \\
\hline 12 & .252 & 43.099 & 12.041 & 3.669 & 1.584 & 28.712 & 2.351 & 8.540 \\
\hline 20 & .274 & 39.372 & 12.902 & 5.792 & 2.0278 & 26.937 & 3.431 & 9.535 \\
\hline \multicolumn{9}{|l|}{ USFFR } \\
\hline 1 & .588 & 6.736 & 72.626 & .094 & 2.461 & 1.909 & 3.631 & 12.539 \\
\hline 3 & 1.010 & 10.710 & 51.770 & .419 & 2.180 & 7.716 & 5.511 & 21.689 \\
\hline 5 & 1.180 & 15.384 & 47.676 & .862 & 6.086 & 6.491 & 6.114 & 17.384 \\
\hline \multicolumn{9}{|l|}{ RGDP } \\
\hline 1 & .030 & 14.041 & 10.074 & 33.389 & 3.706 & 31.253 & 5.494 & 2.039 \\
\hline 3 & .048 & 13.192 & 6.619 & 17.795 & 3.410 & 46.513 & 3.241 & 9.227 \\
\hline 5 & .055 & 12.005 & 7.860 & 17.520 & 3.106 & 47.567 & 3.592 & 8.347 \\
\hline \multicolumn{9}{|l|}{ THCPI } \\
\hline 1 & .014 & 47.909 & 14.683 & 1.283 & 9.795 & 23.319 & .478 & 2.528 \\
\hline 3 & .017 & 37.429 & 13.207 & 2.214 & 7.005 & 30.658 & 1.671 & 7.812 \\
\hline 5 & .020 & 28.420 & 16.679 & 3.547 & 5.415 & 36.086 & 2.159 & 7.691 \\
\hline \multicolumn{9}{|l|}{$\bar{M}$} \\
\hline 1 & .031 & 10.897 & 10.297 & 9.654 & 3.809 & 62.101 & .707 & 2.532 \\
\hline 3 & .053 & 6.5343 & 18.438 & 7.151 & 2.868 & 58.062 & 1.890 & 5.054 \\
\hline 5 & .065 & 4.7908 & 18.894 & 6.705 & 2.885 & 56.8004 & 2.036 & 7.886 \\
\hline \multicolumn{9}{|l|}{ THCBPR } \\
\hline 1 & .646 & 39.877 & 3.765 & 3.809 & 17.225 & 7.671 & 26.138 & 1.511 \\
\hline 3 & .873 & 24.068 & 24.773 & 2.511 & 11.592 & 9.601 & 16.861 & 10.590 \\
\hline 5 & .978 & 22.726 & 28.836 & 2.855 & 10.664 & 8.423 & 14.205 & 12.287 \\
\hline \multicolumn{9}{|l|}{ NEER } \\
\hline 1 & .024 & 8.3898 & 5.582 & 27.96 & 3.331 & 15.723 & 2.261 & 36.750 \\
\hline 3 & .032 & 15.490 & 6.278 & 26.024 & 5.198 & 16.874 & 5.104 & 25.028 \\
\hline 5 & .035 & 15.962 & 7.510 & 23.287 & 5.669 & 17.104 & 6.222 & 24.242 \\
\hline
\end{tabular}

\section{CONCLUSIONS}

This paper highlights the importance of monetary transmission mechanism and investigates the working of Thai monetary policy by using SVAR model with post-crisis quarterly data. The identifying restrictions used in the SVAR seem to appropriately identify a monetary policy shock even though the exchange rate puzzle is found. Some empirical findings are meaningful in economic sense. First, the interest rate remains a dominant channel for monetary policy to output, consistent with the view of Disyatat and Vongsinsirikul (2003) and Kubo (2008). Second, monetary aggregate plays a more domineering role for monetary policy to output and inflation while an exchange rate channel has a decreasing significance. These results are in line with Hesse (2007) and Prasertnukul, Kim, and Kakinaka (2010). In addition, Thailand economy is sensitive to the foreign sector in both the world price of oil and the U.S. monetary 
policy. The results also reveal the linkage and influence of U.S. monetary policy on Thailand monetary policy.

These empirical findings can draw policy implications for Thailand. First, achievement and maintenance of price stability is essential to the sustainable economic growth. An implication is that a low and stable inflation requires a credible rule-based monetary policy with effective monetary transmission mechanism. One of rule-based monetary regimes is inflation targeting which has been widely used in many countries since the 1990s. In general, central banks of inflation targeting countries have run tightening monetary policies by raising the policy interest rate when and if inflationary pressure remains high. As inflation falls further, they will have scope to cut interest rate for stimulating their economy. In the Thailand case, with low-level interest rate at $1 \%-2 \%$ for many years past, there is no ample room to ease monetary policy. Therefore, interest rate instrument may not remain appropriate and effective in monetary transmission mechanism due to price stickiness and low-inflationary environment. This leads to the second policy implication that monetary aggregate should receive significant attention in the conduct of monetary policy because it significantly affects price level and output. This shows that the central bank of Thailand (Bank of Thailand) has an option to deploy a monetary aggregate as a supplementary instrument of monetary policy for price stability. This is especially true if and when, under inflation targeting, the policy interest rate becomes less effective in a low-inflationary environment and when there is concern for inflation volatility (due to excessive money-growth instability) under a form of "flexible" inflation targeting in which a policy interest rate (rather than a monetary aggregate) is deployed as an instrument of monetary policy.

\section{Notes}

1. In the operational sense, price stability means to keep inflation low on average, which is reflected in the pre-set inflation target. It is a necessary condition for sustained economic growth.

2. This indicates that an instrument of monetary policy becomes more effective when the monetary policy transmission mechanism and financial system are well developed and understood (Charoenseang and Manakit 2007b).

3. During 2000 and 2008, the BOT set the core inflation target at 0-3.5 percent. The maintenance of price stability in term of core inflation would lead to overall price stability in the long run. The core inflation is expressed as year-on-year percentage change of consumer price index excluding fresh food and energy. In 2009, the monetary policy committee (MPC) considered appropriateness of inflation target. The MPC and Ministry of Finance adjusted a new inflation target by narrowing the target to $0.5-3.0$ percent per annum. In 2015, the new monetary policy target has been proposed. The new target is set for annual average of headline inflation to be at 2.5 percent with a band of \pm 1.5 percent.

4. Examples of SVAR literature for Thailand include Atchariyachanvanich (2004), Hesse (2007), Kubo (2008), Patrawimolpon et al. (2001), Sek (2009), and Vimolsiri and Hirunraengchok (2004).

5. In other words, regarding to the B matrix, it is assumed to be diagonal. In order for the model to be just-identified, $2 n^{2}-$ $n(n+1) 2=70$ restrictions are required. Since the number of restrictions is greater than 70 , the model is over-identified.

6. The Akaike, Schwarz, or Hannan-Quinn information criteria are used in selecting the optimal lag length.

7. The unit root test results are available upon the request.

8. The detail results of the contemporaneous coefficients, impulse response functions, and forecast error variance decomposition are available upon request.

9. The impulse response functions that contradict the theory predictions are known as empirical puzzles. Four empirical puzzles have been found in the monetary literatures that study the effects of monetary policy. First, the output puzzle refers to an increase in output in response to a monetary policy tightening. Second, the liquidity puzzle refers to an increase in monetary aggregate in response to a positive shock in nominal interest rate (monetary policy shocks). Third, the price puzzle is relevant to an increase (rather than decrease) in the price level in response to a shock (say an increase) in the interest rate (a contractionary policy shocks). In other words, as the central bank increases 
interest rates (or contracts the money supply) in attempt to contain inflation in the economy, the price tends to increase further. Fourth, the exchange rate puzzle refers to the depreciation (rather than appreciation) of domestic currency in response to a contractionary monetary policy shock.

\section{References}

Afandi, A. 2005. "Monetary Policy Transmission Mechanism and Structural Breaks in Indonesia." Doctoral of Philosophy, University of Wollongong.

Amisano, G. and C. Giannini. 1997. Topics in Structural VAR Econometrics. Springer Berlin Heidelberg.

Atchariyachanvanich, W. 2004. "VAR Analysis of Monetary Policy Tranmission Mechanisms: Empirical Study on Five Asian Countries After the Asian Crisis." Forum of International Development Studies 25:39-59.

Bernanke, B. 1986. "Alternative Explanations of the Money-Income Correlation.” Carnegie-Rochester Conference Series on Public Policy 25(1):49-59.

Bernanke, B. and A. Blinder. 1988. "Credit, Money, and Aggregate Demand." The American Economic Review 78(2):435-439.

- 1992. "The Federal Funds Rate and the Channels of Monetary Transmission.” The American Economic Review 82(4):901-921.

Bernanke, B. and M. Gertler. 1995. "Inside the Black Box: The Credit Channel of Monetary Policy Transmission.” Journal of Economic Perspectives 9(4):27-48.

Charoenseang, J. and P. Manakit. 2007a. "Financial Crisis and Restructuring in Thailand." Pp. 83-106 in Economic Dynamism of Asia in the New Millenium: From the Asian Crisis to a New Stage of Growth, edited by Y. Shimizu. Hackensack, N.J. and Singapore: World Scientific.

—. 2007b. "Thai Monetary Policy Transmission in an Inflation Targeting Era.” Journal of Asian Economics 18(1):144-157.

Cushman, D. O. and T. Zha. 1997. "Identifying Monetary Policy in a Small Open Economy Under Flexible Exchange Rates.” Journal of Monetary Economics 39(3):433-448.

Disyatat, P. and P. Vongsinsirikul. 2003. "Monetary Policy and the Transmission Mechanism in Thailand." Journal of Asian Economics 14(3):389-418.

Dungey, M. and A. Pagan. 2000. "A Structural VAR Model of the Australian Economy." The Economic Record 76(235):321-342.

- 2009. "Extending a SVAR Model of the Australian Economy.” The Economic Record 85(268):1-20.

Fung, B. S. C. 2002. A VAR Analysis of the Effects of Monetary Policy in East Asia. Bank for International Settlements. Retrieved (http://www.bis.org/publ/work119.pdf).
Grenville, S. and T. Ito. 2010. An Independent Evaluation of the Bank of Thailand's Monetary Policy Under the Inflation Targeting Framework, 2000-2010. Bank of Thailand. Retrieved (https://www.bot.or.th/Thai/MonetaryPolicy/.../ GrenvilleItoV10(Oct22).pdf).

Hesse, H. 2007. "Monetary Policy, Structural Break and the Monetary Transmission Mechanism in Thailand.” Journal of Asian Economics 18(4):649-669.

Hossain, A. 2009. Central Banking and Monetary Policy in the Asia-Pacific. Cheltenham and London: Edward Elgar.

Kim, S. and N. Roubini. 2000. "Exchange Rate Anomalies in the Industrial Countries: A Solution With a Structural VAR Approach." Journal of Monetary Economics 45(3):561-586.

Kubo, A. 2008. "Macroeconomic Impact of Monetary Policy Shocks: Evidence From Recent Experience in Thailand.” Journal of Asian Economics 19(1):83-91.

Lane, T., A. Ghosh, J. Hamann, S. Phillips, M. Schultze-Ghattas, and T. Tsikata. 2000. IMF-Supported Programs in Indonesia, Korea, and Thailand: A Preliminary Assessment. Retrieved (https://www.imf.org/ external/pubs/ft/op/op178/OP178.pdf).

Mishkin, F. S. 1995. "Symposium on the Monetary Transmission Mechanism." Journal of Economic Perspectives 9(4):3-10.

Nakornthab, D. 2009. “Thailand's Monetary Policy Since the 1997 Crisis.” Kobe University Economic Review 55:75-88.

Patrawimolpon, P., T. Rattanalankar, C. Charumilind, and P. Ngamchant. 2001. A Structural Vector Autoregressive Model of Thailand: A Test for Structural Shifts. Retrieved (http://econ.tu.ac.th/archan/RANGSUN/EC\%20460/EC\%2 0460\%20Readings/Thai\%20Economy/Structure\%20of\%20 Thai\%20Economy/Structural\%20Vector\%20Autoregressiv e\%20Model\%20of\%20Thai.pdf).

Prasertnukul, W., D. Kim, and M. Kakinaka. 2010. "Exchange Rates, Price Levels, and Inflation Targeting: Evidence From Asian Countries.” Japan and the World Economy 22(3):173-182.

Raghavan, M., P. Silvapulle, and G. Athanasopoulos. 2012. "Structural VAR Models for Malaysian Monetary Policy Analysis During the Pre- and Post-1997 Asian Crisis Periods.” Applied Economics 44(29):3841-3856.

Sek, S. K. 2009. "Interactions Between Monetary Policy and Exchange Rate in Inflation Targeting Emerging Countries: The Case of Three East Asian Countries.” International Journal of Economics and Finance 1(2):27-44.

Sims, C. A. 1986. "Are Forecasting Models Usable for Policy Analysis?” Quarterly Review, Federal Reserve Bank of Minneapolis 2-16. Retrieved (https://www.minneapolisfed. org/research/qr/qr1011.pdf).

Taylor, J. B. 1995. "The Monetary Transmission Mechanism: An Empirical Framework." Journal of Economic 
Perspectives 9(4):11-26.

Vimolsiri, P. and A. Hirunraengchok. 2004. "Structural Vector Autoregressions: The Case of Thailand.” Presented at the International Symposium on Forecasting, July 4-7, 2004, Sydney.

\section{Bio}

Popkarn Arwatchanakarn, Ph.D. candidate, Newcastle Business School, The University of Newcastle, Australia; research fields: macroecnomics, monetary economics. 